\title{
Effect of intra row spacing, dates of haulm cutting and fertilizer dose on disease free quality seed tuber production of potato (Solanum tuberosum L.) under new Alluvial Zone of West Bengal
}

Manoj Mandal

AICRP on Potato, Directorate of Research, Bidhan Chandra Krishi Viswavidyalaya, Kalyani-741235 Nadia (West Bengal), India

Sanjib Kumar Das*

AICRP on Potato, Directorate of Research, Bidhan Chandra Krishi Viswavidyalaya, Kalyani-741235 Nadia (West Bengal), India

*Corresponding author. E-mail: sanjibag@gmail.com

\section{Abstract}

Potato (Solanum tuberosum L.) is the most popular tuber crop in West Bengal, India. Seed tuber is the single most important factor in potato cultivation and if the seed is not of good quality, then optimum production could not be achieved. Unavailability of good quality seed, high price and untimely supply of seed at the village level are the main limiting factors in potato production. Field experiments were conducted during rabi season of 2017-18 and 2018-19 at Bidhan Chandra Krishi Viswavidyalaya, Kalyani, West Bengal to determine the effects of intra row spacing, dates of haulm cutting and fertilizer dose on disease free quality seed grade tuber production of potato. The experiment was laid out in a split split plot design with three replications having twelve treatment combinations. The results revealed that with the decrease in intra row spacing from $20 \mathrm{~cm}$ to $15 \mathrm{~cm}$ seed grade size $(<75 \mathrm{~g})$ tuber yield and numbers and total tuber numbers were significantly increased but marketable grade $(>75 \mathrm{~g}$ ) tuber yield and numbers were significantly reduced. Haulm cutting at 65 DAP increased the seed grade size tuber yield and numbers over 75 DAP. With the decrease in fertility levels from $100 \%$ RDF of NPK to $50 \%$ RDF of NPK the seed grade tuber production and number were significantly increased at $5 \%$ level of significance. Disease incidence and intensity of Phoma leaf spot decreased and early blight increased with decreasing doses of fertilizers. No viral disease was observed. Dehaulming at 65 DAP was found safer so far as infestation and chances of viral disease transmission by the sucking pests were concerned. From the present study it may be concluded that, for quality seed tuber production of potato and to get highest net return under New Alluvial Zone of West Bengal, use of $50 \mathrm{~cm} \times 15 \mathrm{~cm}$ spacing along with haulm cutting at 65 DAP, when planting is done on first week of November and grown with $50 \%$ RDF of NPK was found best.

Keywords: Dates of haulm cutting, Fertility levels, Potato, Seed tuber Production, Spacing

\section{INTRODUCTION}

West Bengal is the second largest potato growing state in India with a production of 10.0 million tonnes from an area of 409.7 thousand hectares. (Directorate of Agriculture, WB, 2018). The state accounts for one-third of the country's total potato production (Anonymous, 2019). Potato is the most popular crop in West Bengal next to the cereals. The crop is mostly grown during winter season (November-March). Seed tuber is the single most important factor in potato cultivation, which accounts for nearly $40-50 \%$ of the total investment for raising the crop, and if the seed is not of good quality, then optimum production could not be achieved (Chakraborty et al., 2013). Unavailability of good quality seed, high price and untimely sup-

\section{Article Info}

https://doi.org/

10.31018/jans.v12i1.2204

Received: December 15, 2019

Revised: January 14, 2020

Accepted: January 22, 2020

\section{How to Cite}

Mandal, M. and Das, S.K (2020). Effect of intra row spacing, dates of haulm cutting and fertilizer dose on disease free quality seed tuber production of potato (Solanum tuberosum L.) under new Alluvial Zone of West Bengal . Journal of Applied and Natural Science, 12(1): 1 - 8 https://doi.org/10.31018/ jans.v12i1.2204 
growing potato acreage in the plains. In West Bengal potato seed tuber can be produced if early planting is adopted. Moreover, the critical level of aphid population (20 aphids per 100 compound leaves) generally appears on $2^{\text {nd }}$ week of January onwards. As a results 8-9 weeks of low aphid pressure period is available, and the problem of viral disease infection is much lower during this period. More over as potato is a vegetatively propagated crop and requires huge amount of fertilizers thus making the crop susceptible to so many diseases like late blight, early blight, phoma leaf spot etc and to combat these diseases appropriate management strategies are needed to produce disease free quality seed tuber of potato. Presently, the farmers of this state have no other option but to depend upon the homegrown seed or buy it from the cold stores, open market and seeds from other states at higher prices. In most of the cases, poor quality of seed material causes lower yield. The only solution left for the farmers of this state is to produce their own seed by following the 'Seed Plot Technique' (Wurr, 1978). Approximately $30-40 \%$ of the seed potato is procured from outside the state like Punjab, U.P etc. the quality of which is not always good enough resulting in rapid degeneration of tubers due to viral disease (Mondal et al., 2015). Not only that, cost of such seed tubers is also very high resulting in huge monitory loss. Therefore, to save the farmers from losses and to make the potato cultivation profitable an effort has been made to produce potato seed in the state itself. Keeping the above facts in view, this experiment was initiated with the objectives to study the effect of intra row spacing, dates of haulm cutting and fertilizer dose on disease free quality seed grade tuber production of potato through 'Seed plot technique' under New Alluvial Zone of West Bengal.

\section{MATERIALS AND METHODS}

Field experiments were conducted for two years at C-unit research farm (Kalyani) of Bidhan Chandra Krishi Viswavidyalaya, Nadia, West Bengal, India situated at $22^{\circ} 58^{\prime} \mathrm{N}$ latitude and $88^{\circ} 3^{\prime} \mathrm{E}$ longitude with an altitude of $9.75 \mathrm{~m}$ above mean sea (MSL) during rabi 2017-18 and 2018-19. The soil of the experimental field was sandy loam in texture and slightly alkaline in reaction $(\mathrm{pH} 7.2)$ having an organic carbon content of $0.57 \%, 183.26$ $\mathrm{Kg}$ available $\mathrm{N}$ ha ${ }^{-1}, 16.8 \mathrm{~kg}$ available $\mathrm{P}_{2} \mathrm{O}_{5} \mathrm{ha}^{-1}$, $132 \mathrm{~kg}$ available $\mathrm{K}_{2} \mathrm{O} \mathrm{ha}{ }^{-1}$. The experiment was laid out in a split split plot design with three replications having twelve treatment combinations viz. two levels of spacing, $51-50 \mathrm{~cm} \times 20 \mathrm{~cm}$ and $\mathrm{S} 2-$ $50 \mathrm{~cm} \times 15 \mathrm{~cm}$ were applied in main plots. Two levels of dates of haulm cutting, $\mathrm{H} 1-65$ days after planting (DAP) and $\mathrm{H} 2-75$ days after planting were applied in sub plots and three levels of fertility levels, F1- 100\% RDF (Recommended dose of fertilizer) of NPK, F2- 75\% RDF of NPK, F3- 50\% RDF of NPK were applied in sub sub plots with a plot size of $5 \mathrm{~m} \times 3 \mathrm{~m}$. Breeder seeds of potato variety Kufri Himalini was planted on 5th November maintaining proper seed plot techniques. Tubers weighing $30-40 \mathrm{~g}$ each were planted in the furrows with a depth of planting of $3-4 \mathrm{~cm}$ and finally covered with soil. Nitrogen $(\mathrm{N})$, phosphorus $(\mathrm{P})$ and potassium $(\mathrm{K})$ were applied through urea, single super phosphate and muriate of potash respectively. The recommended dose of fertilizer (RDF) was 200, 150, $150 \mathrm{~kg} \mathrm{~N}, \mathrm{P}_{2} \mathrm{O}_{5}, \mathrm{~K}_{2} \mathrm{O} \mathrm{ha}^{-1}$. Half of nitrogen, full dose of phosphorus and potassium were applied as basal as per treatment details. Rest half $\mathrm{N}$ was top dressed at 30 days after planting (DAP) followed by earthing up. Preemergence application of Sencor (Metribuzin) @ $0.75 \mathrm{~kg}$ a.i. $\mathrm{ha}^{-1}$ was done at 3 DAP followed by 1 hand-weeding at 20 DAP to promote early crop growth. As a prophylactic measure, spraying (twice) with Dithane M-45 (Mancozeb) @ 0.2\% at 40 and 60 DAP was done against late blight. Imidacloprid 17.8SL @0.03\% was also sprayed (thrice) at 30, 40 and 60 DAP for controlling aphids and other sucking insects. Continuous monitoring and roughing was done. Dehaulming was done as per treatments. For $\mathrm{H} 1$ haulm cutting was done on 09.01.18 and 09.01.19, and for $\mathrm{H} 2$ haulm cutting was done on 19.01.18 and 19.01.19 and harvesting was done 10 days after haulm cutting, and the crop lines were opened with the help of plough. Potato tubers were dug out from each plot manually. Data on grade wise tuber number and yield and total tuber number and yield were recorded at harvest from each net plot area. Percent disease incidence [(No. of infected plants / Total no. of plants) X100] and intensity [using 1-9 scale for late blight, Malcolimson, 1976 and 1-5 scale for phoma leaf spot and early blight, Kumar et al. (2017)] and aphid population build up were studied. Analysis of variance of the data in the experimental design and comparison of means at $p \leq 0.05$ were carried out, using MSTAT-C software.

\section{RESULTS AND DISCUSSION}

Effect on plant emergence, plant height and no. of shoots per plant: Experimental results revealed that plant emergence of potato was not significantly influenced by intra row spacing, dates of haulm cutting and fertility levels and their interactions (Table 1). Plant height of potato variety Kufri Himalini at 60 DAP crop growth and no. of shoots per plant of potato were not significantly influenced by different effects of spacing and dates of haulm cutting but it was significantly affected by fertility levels._The highest plant height $(73.18 \mathrm{~cm})$ was recorded at $100 \%$ RDF of NPK. Decrease in fertility levels from $100 \%$ RDF of NPK to $50 \%$ RDF of NPK significantly reduced the plant 
Mandal, M. and Das, S.K. / J. Appl. \& Nat. Sci. 12(1): 1 - 8 (2020)

Table 1. Effects of spacing, dates of haulm cutting and fertilizer doses on emergence, plant height and no. of shoots per plant of potato (Pooled data of two years).

\begin{tabular}{llll}
\hline Treatment & \multicolumn{2}{c}{ Potato } \\
\cline { 2 - 4 } & Emergence (\%) & Plant height (cm) & No. of shoots plant \\
\hline Levels of spacing & 99.66 & 71.61 & 3.14 \\
S1 & 99.77 & 70.68 & 3.07 \\
S2 & 0.15 & 0.24 & 0.03 \\
S.E $E_{m}( \pm)$ & $\mathrm{NS}$ & $\mathrm{NS}$ & $\mathrm{NS}$ \\
$\mathrm{CD}(\mathrm{P}=0.05)$ & & & \\
Levels of dates of haulm cutting & 99.63 & 71.36 & 3.10 \\
$\mathrm{H} 1$ & 99.79 & 70.94 & 3.12 \\
$\mathrm{H} 2$ & 0.04 & 0.18 & 0.04 \\
S.E & $\mathrm{NS}( \pm)$ & $\mathrm{NS}$ & $\mathrm{NS}$ \\
$\mathrm{CD}(\mathrm{P}=0.05)$ & & & \\
Levels of fertility & 99.78 & 73.18 & 3.38 \\
$\mathrm{~F} 1$ & 99.75 & 70.94 & 3.08 \\
F2 & 99.61 & 69.32 & 2.87 \\
F3 & 0.12 & 0.32 & 0.04 \\
S.E & $( \pm)$ & 0.95 & 0.12 \\
CD $(P=0.05)$ & $\mathrm{NS}$ & & \\
\hline
\end{tabular}

Table 2. Effects of spacing, dates of haulm cutting and fertilizer doses on grade wise and total tuber yield of potato (Pooled data of two years).

\begin{tabular}{|c|c|c|c|c|c|c|c|}
\hline \multirow[t]{2}{*}{ Treatment } & \multicolumn{5}{|c|}{ Grade-wise yield of tubers $\left(\mathrm{t} \mathrm{ha}^{-1}\right)$} & \multicolumn{2}{|c|}{$\begin{array}{l}\text { Yield on dry weight } \\
\text { basis }\left(\mathrm{t} \mathrm{ha}^{-1}\right)\end{array}$} \\
\hline & $0-25 g$ & $25-50 \mathrm{~g}$ & $50-75 \mathrm{~g}$ & $>75 g$ & Total & Tuber & Haulm \\
\hline \multicolumn{8}{|c|}{ Levels of spacing } \\
\hline S1 & 3.00 & 6.34 & 6.90 & 13.23 & 29.47 & 5.76 & 3.45 \\
\hline S2 & 3.78 & 7.23 & 8.69 & 12.96 & 32.66 & 5.81 & 3.49 \\
\hline S.E $E_{m}( \pm)$ & 0.14 & 0.18 & 0.08 & 0.20 & 0.11 & 0.08 & 0.05 \\
\hline$C D(P=0.05)$ & NS & NS & 0.48 & NS & 0.65 & NS & NS \\
\hline \multicolumn{8}{|c|}{ Levels of dates of haulm cutting } \\
\hline $\mathrm{H} 1$ & 3.70 & 6.83 & 7.81 & 12.02 & 30.36 & 5.70 & 3.42 \\
\hline $\mathrm{H} 2$ & 3.08 & 6.73 & 7.78 & 14.17 & 31.77 & 5.87 & 3.52 \\
\hline S.E ${ }_{m}( \pm)$ & 0.09 & 0.20 & 0.13 & 0.15 & 0.20 & 0.06 & 0.03 \\
\hline$C D(P=0.05)$ & 0.35 & NS & NS & 0.58 & 0.78 & NS & NS \\
\hline \multicolumn{8}{|c|}{ Levels of fertility } \\
\hline F1 & 2.88 & 6.55 & 6.91 & 18.95 & 35.30 & 6.41 & 3.85 \\
\hline $\mathrm{F} 2$ & 3.22 & 6.68 & 8.11 & 12.75 & 30.77 & 5.68 & 3.41 \\
\hline F3 & 4.07 & 7.12 & 8.37 & 7.58 & 27.14 & 5.26 & 3.16 \\
\hline S.E $E_{m}( \pm)$ & 0.14 & 0.17 & 0.31 & 0.33 & 0.55 & 0.11 & 0.07 \\
\hline$C D(P=0.05)$ & 0.40 & NS & 0.92 & 0.99 & 1.66 & 0.34 & 0.21 \\
\hline
\end{tabular}

height and no. of shoots per plant of potato. Decrease in plant height and no. of shoots per plant of potato with decreasing fertility levels was confirmed by Das et al. (2016). In case of effect of fertility levels the highest no of shoots per pant (3.38 no.) was recorded at $100 \%$ RDF of NPK. However, the interaction effect of treatments on plant height and no. of shoots per plant of potato were found statistically insignificant at $5 \%$ level of significance.

Effect on grade wise and total tuber yield: Experimental results revealed that, seed grade $(<75 \mathrm{~g})$ tuber yield and total tuber yield of potato were significantly influenced by intra row spacing, dates of haulm cutting and fertilizer doses. Results showed that $50-75 \mathrm{~g}$ grade and total tuber production of potato was significantly influenced by spacing (Table. 2). With the decrease in intra row spacing seed grade tuber yield and total tuber yield were significantly increased but $>75 \mathrm{~g}$ grade tuber yield was significantly reduced. Lower spacing also increased the $0-25 \mathrm{~g}$ grade and $25-50 \mathrm{~g}$ grade tuber yield, which was desirable to produce more amount of seed grade size tuber of potato. The result corroborated with the findings of Dua et al. (2008) and Das et al. (2016) for potato crops at Shimla and Kalyani regions of India respectively. Haulm cutting at 65 DAP increased the seed grade size $(<75 \mathrm{~g})$ tuber yield over haulm cutting at 75 DAP. However, haulm cutting at 75DAP significantly increased the marketable tuber (> $75 \mathrm{~g}$ ) yield and total tuber production at $5 \%$ level of significance. This result corroborated with the findings of Lal and Sahota (1983) and Das et al. (2016). With the decrease in fertility levels from $100 \%$ RDF of NPK to $50 \%$ RDF of NPK the seed grade $(<75$ g) tuber yield was significantly increased but marketable grade tuber yield ( $>75 \mathrm{~g}$ ), total tuber yield 
Mandal, M. and Das, S.K. / J. Appl. \& Nat. Sci. 12(1): 1 - 8 (2020)

Table 3. Effects of spacing, dates of haulm cutting and fertilizer doses on grade wise and total tuber number of Potato (Pooled data of two years).

\begin{tabular}{|c|c|c|c|c|c|}
\hline \multirow[t]{2}{*}{ Treatment } & \multicolumn{5}{|c|}{ Grade-wise number of tubers (nos. ha $^{-1}$ ) } \\
\hline & $0-25 g$ & $25-50 \mathrm{~g}$ & $50-75 \mathrm{~g}$ & $>75 \mathrm{~g}$ & Total \\
\hline \multicolumn{6}{|c|}{ Levels of spacing } \\
\hline S1 & 180093 & 161574 & 105093 & 96759 & 543518 \\
\hline S2 & 231019 & 200463 & 141204 & 85185 & 657870 \\
\hline S.E $E_{m}( \pm)$ & 5792 & 4428 & 982 & 1823 & 9729 \\
\hline $\mathrm{CD}(\mathrm{P}=0.05)$ & 35731 & 27321 & 6059 & 11245 & 60024 \\
\hline \multicolumn{6}{|c|}{ Levels of dates of haulm cutting } \\
\hline $\mathrm{H} 1$ & 220833 & 189352 & 126389 & 86111 & 622685 \\
\hline $\mathrm{H} 2$ & 190278 & 172685 & 119907 & 95833 & 578704 \\
\hline $\mathrm{S} \mathrm{E}_{\mathrm{m}}( \pm)$ & 7768 & 7371 & 1669 & 1464 & 11871 \\
\hline$C D(P=0.05)$ & 30327 & NS & NS & 5716 & NS \\
\hline \multicolumn{6}{|c|}{ Levels of fertility } \\
\hline $\mathrm{F} 1$ & 171528 & 161806 & 102778 & 109722 & 545833 \\
\hline $\mathrm{F} 2$ & 206250 & 182639 & 127778 & 93056 & 609722 \\
\hline F3 & 238889 & 198611 & 138889 & 70139 & 646528 \\
\hline S.E $E_{m}( \pm)$ & 6371 & 5720 & 5475 & 1985 & 11305 \\
\hline$C D(P=0.05)$ & 19103 & 17149 & 16417 & 5950 & 33896 \\
\hline
\end{tabular}

Table 4. Observation on disease incidence in the experimental field of potato (Mean data of two years).

\begin{tabular}{|c|c|c|c|c|c|c|c|}
\hline \multirow[t]{2}{*}{ Treatment } & \multicolumn{2}{|c|}{ Phoma (\%) } & \multicolumn{2}{|c|}{ Early blight (\%) } & \multicolumn{2}{|c|}{ Late Blight (\%) } & \multirow{2}{*}{ Viral Disease } \\
\hline & Incidence & Intensity & Incidence & Intensity & Incidence & Intensity & \\
\hline (S1H1F1) & 8.35 & 2.00 & 3.50 & 2.25 & 0.00 & 0.00 & 0.00 \\
\hline (S1H1F2) & 8.00 & 1.50 & 4.00 & 2.50 & 0.00 & 0.00 & 0.00 \\
\hline (S1H1F3) & 7.25 & 1.50 & 4.50 & 2.50 & 0.00 & 0.00 & 0.00 \\
\hline (S1H2F1) & 10.30 & 2.50 & 5.00 & 2.50 & 0.00 & 0.00 & 0.00 \\
\hline$(\mathrm{S} 1 \mathrm{H} 2 \mathrm{~F} 2)$ & 7.45 & 2.00 & 6.00 & 3.00 & 0.00 & 0.00 & 0.00 \\
\hline (S1H2F3) & 6.65 & 1.50 & 7.50 & 3.70 & 0.00 & 0.00 & 0.00 \\
\hline (S2H1F1) & 11.50 & 2.80 & 5.50 & 3.00 & 0.00 & 0.00 & 0.00 \\
\hline (S2F1F2) & 10.45 & 2.00 & 5.75 & 3.50 & 0.00 & 0.00 & 0.00 \\
\hline (S2H1F3) & 10.00 & 1.50 & 6.25 & 3.50 & 0.00 & 0.00 & 0.00 \\
\hline (S2H2F1) & 15.00 & 3.20 & 6.50 & 3.00 & 0.00 & 0.00 & 0.00 \\
\hline$(\mathrm{S} 2 \mathrm{H} 2 \mathrm{~F} 2)$ & 10.00 & 3.00 & 10.00 & 4.00 & 0.00 & 0.00 & 0.00 \\
\hline$(\mathrm{S} 2 \mathrm{H} 2 \mathrm{~F} 3)^{\prime}$ & 9.00 & 2.35 & 10.00 & 4.50 & 0.00 & 0.00 & 0.00 \\
\hline
\end{tabular}

Table 5. Observation on aphid infestation in the experimental field of potato (Mean data of two years).

\begin{tabular}{lllllll}
\hline Treatment & \multicolumn{7}{c}{ Population of aphid per 100 compound leaves } \\
\cline { 2 - 6 } & $\mathbf{0 3 . 0 1 . 1 8}$ & $\mathbf{0 3 . 0 1 . 1 9}$ & $\mathbf{1 0 . 0 1 . 1 8}$ & $\mathbf{1 0 . 0 1 . 1 9}$ & $\mathbf{1 7 . 0 1 . 1 8}$ & $\mathbf{1 7 . 0 1 . 1 9}$ \\
\hline (S1H1F1) & 0.00 & 0.00 & 0.00 & 0.00 & - & - \\
(S1H1F2) & 0.00 & 0.00 & 0.00 & 0.00 & - & - \\
(S1H1F3) & 0.00 & 0.00 & 0.00 & 0.00 & - & - \\
(S1H2F1) & 0.00 & 0.00 & 0.00 & 0.00 & 0.00 & 2.25 \\
(S1H2F2) & 0.00 & 0.00 & 0.00 & 0.00 & 0.00 & 2.00 \\
(S1H2F3) & 0.00 & 0.00 & 0.00 & 0.00 & 0.00 & 1.75 \\
(S2H1F1) & 0.00 & 0.00 & 0.00 & 0.00 & - & - \\
(S2F1F2) & 0.00 & 0.00 & 0.00 & 0.00 & - & - \\
(S2H1F3) & 0.00 & 0.00 & 0.00 & 0.00 & - & - \\
(S2H2F1) & 0.00 & 0.00 & 0.00 & 0.00 & 0.00 & 2.40 \\
(S2H2F2) & 0.00 & 0.00 & 0.00 & 0.00 & 0.00 & 2.15 \\
(S2H2F3) & 0.00 & 0.00 & 0.00 & 0.00 & 0.00 & 1.80 \\
\hline
\end{tabular}

and dry weight yield of tubers were significantly decreased. This was in conformity with the results of Dua et al. (2008), Chakraborty et al. (2013) and Das et al. (2016) for potato crops at Shimla, Hooghly and Kalyani regions of India respectively. The highest total tuber yield $\left(35.30 \mathrm{t} \mathrm{ha}^{-1}\right)$ was recorded with $100 \%$ RDF of NPK. However, the interactions were found mostly non significant. Effect on grade wise tuber numbers and total tuber numbers: Experimental results revealed that, grade wise tuber numbers and total tuber numbers of potato were significantly influenced by spacing (Table. 3). With the decrease in intra row spacing from $20 \mathrm{~cm}$ to $15 \mathrm{~cm}$ seed grade size (< $75 \mathrm{~g}$ ) tuber numbers and total tuber numbers were significantly increased but marketable grade ( $>75$ g) tuber number was significantly reduced, which is desirable to produce more numbers of seed 
Mandal, M. and Das, S.K. / J. Appl. \& Nat. Sci. 12(1): 1 - 8 (2020)

Table 6. Effect of spacing, dates of haulm cutting and fertilizer doses on post-harvest soil nutrient status.

\begin{tabular}{|c|c|c|c|}
\hline \multirow[t]{2}{*}{ Treatment } & \multicolumn{3}{|c|}{ Post-harvest soil nutrient $\left(\mathrm{kg} \mathrm{ha}^{-1}\right)$ status } \\
\hline & Nitrogen & Phosphorus & Potassium \\
\hline \multicolumn{4}{|c|}{ Levels of spacing } \\
\hline S1 & 178.89 & 18.14 & 130.20 \\
\hline S2 & 178.24 & 18.09 & 129.49 \\
\hline S.E $E_{m}( \pm)$ & 0.72 & 0.09 & 0.40 \\
\hline$C D(P=0.05)$ & NS & NS & NS \\
\hline \multicolumn{4}{|c|}{ Levels of dates of haulm cutting } \\
\hline $\mathrm{H} 1$ & 178.92 & 18.21 & 130.20 \\
\hline $\mathrm{H} 2$ & 178.20 & 18.02 & 129.50 \\
\hline S.E $E_{m}( \pm)$ & 0.65 & 0.07 & 0.32 \\
\hline$C D(P=0.05)$ & NS & NS & NS \\
\hline \multicolumn{4}{|c|}{ Levels of fertility } \\
\hline F1 & 176.58 & 17.82 & 128.63 \\
\hline $\mathrm{F} 2$ & 179.38 & 18.26 & 130.31 \\
\hline F3 & 179.73 & 18.28 & 130.60 \\
\hline S.E $E_{m}( \pm)$ & 0.87 & 0.13 & 0.62 \\
\hline $\mathrm{CD}(\mathrm{P}=0.05)$ & 2.60 & 0.40 & 1.86 \\
\hline
\end{tabular}

Table 7. Effect of spacing, dates of haulm cutting and fertility level on total nutrient uptake by potato.

\begin{tabular}{llll}
\hline Treatment & \multicolumn{3}{c}{ Nutrient uptake (kg ha $\left.\mathbf{~}^{-1}\right)$ by Potato } \\
\cline { 2 - 4 } & Nitrogen & Phosphorus & Potassium \\
\hline Levels of spacing & & & 185.73 \\
\hline S1 & 133.32 & 36.78 & 186.82 \\
S2 & 134.10 & 36.99 & 0.19 \\
S.E $E_{m}( \pm)$ & 0.13 & 0.04 & 1.01 \\
CD $(P=0.05)$ & 0.72 & NS & \\
Levels of dates of haulm cutting & & & 183.77 \\
H1 & 131.91 & 36.39 & 188.77 \\
H2 & 135.51 & 37.38 & 0.86 \\
S.E $( \pm)$ & 0.58 & 0.20 & 3.20 \\
CD $(P=0.05)$ & 2.40 & 0.86 & 206.47 \\
Levels of fertility & & & 182.80 \\
F1 & 148.21 & 40.89 & 169.56 \\
F2 & 131.22 & 36.20 & 4.20 \\
F3 & 121.71 & 33.58 & 12.60 \\
S.E & 3.10 & 0.80 & \\
CD $(P=0.05)$ & 9.30 & 2.40 & \\
\hline
\end{tabular}

grade size tuber of potato. The result corroborated with the findings of Dua et al. (2008) and Das et al. (2016). Haulm cutting at 65 DAP increased the seed grade size $(<75 \mathrm{~g})$ tuber numbers and total tuber numbers of potato and significantly reduced the marketable grade ( $>75 \mathrm{~g}$ ) tuber numbers. Similar findings were also reported by Mahmud et al. (2009) and Garg et al. (1999) for potato crops at Bangladesh and Shimla hills of India respectively. However, the effect of dates of haulm cutting on total tuber number was found statistically insignificant. Fertility levels had a significant effect on grade wise and total tuber numbers of potato. With the decrease in fertility levels from $100 \%$ RDF of NPK to $50 \%$ RDF of NPK the seed grade size $(<75 \mathrm{~g})$ tuber numbers and total tuber numbers were significantly increased but marketable grade $(>75 \mathrm{~g})$ tuber numbers were significantly decreased. Similar result was also reported by Dua et al. (2008) and Das et al. (2016) for potato crops at Shimla and Kalyani regions of India respectively. This result is desirable for potato seed tuber production as large size tubers $(>80 \mathrm{~g})$ are discarded under potato seed tuber certification process in the state. Benefits of small sized tubers to be treated as seed was also reported by Wurr et al. (2001). However, the interaction effects between intra row spacing, dates of haulm cutting and fertilizer dose were found non significant at $5 \%$ level of significance.

Disease incidence: In this experiment late blight was not observed at all in both the years of study (Table 4) because in both the years the crop was dehaulmed before appearance of late blight. As far as leaf spot disease is concerned both phoma and early blight was observed. Both spacing and fertilizer dose had a marked effect on disease incidence and severity. Highest phoma leaf spot incidence $(15.00 \%)$ and intensity $(3.20 \%)$ was observed when spacing was $50 \mathrm{~cm} \times 20 \mathrm{~cm}$ and $100 \%$ RDF of NPK. With same spacing the disease incidence and intensity decreased with decreasing dose of fertilizers i.e. $75 \%$ RDF of NPK and $50 \%$ RDF of NPK respectively. When the 
Mandal, M. and Das, S.K. / J. Appl. \& Nat. Sci. 12(1): 1 - 8 (2020)



spacing was increased to $50 \mathrm{~cm} \times 20 \mathrm{~cm}$ from the spacing $50 \mathrm{~cm} \times 15 \mathrm{~cm}$ the disease incidence and intensity started decreasing. Minimum disease incidence $(6.65 \%)$ and intensity $(1.50 \%)$ was observed when the spacing was $50 \mathrm{~cm} \times 20 \mathrm{~cm}$ with $50 \%$ RDF of NPK. But in case of early blight, the disease incidence and intensity was increased with decreasing fertilizer dose. Barclay et al. (1973) also reported that both high nitrogen and low phosphorus treatments significantly reduced the incidence of early blight and the combination of high nitrogen and low phosphorus consistently gave the lowest incidence of the disease. Highest early blight incidence $(10.00 \%)$ and intensity $(4.50 \%)$ was observed when spacing was $50 \mathrm{~cm} \mathrm{X}$ $15 \mathrm{~cm}$ and fertilizer dose was $50 \%$ RDF of NPK. Minimum early blight incidence (3.50\%) and intensity $(2.25 \%)$ was recorded at a spacing of $50 \mathrm{~cm} \mathrm{X}$ $20 \mathrm{~cm}$ and fertilizer dose $100 \%$ RDF of NPK. Decrease in early blight incidence with the increase in fertility levels was also confirmed by Mitra et al. (2014) for potato crop at new alluvial zone of West Bengal. No viral disease was observed during both the years. This may be due to intensive insecticide application since thirty days after planting of the crop.

Aphid incidence: The data recorded on aphid population clearly showed (Table 5 ) that no aphid infestation was found during the entire crop growth period in first year. Whatever little population of aphids observed during the second year of experiment on $17^{\text {th }}$ January was much below the critical level of aphid population (20 aphids per 100 compound leaves) and was easily controlled by the prophylactic measures taken and continuous roughing operation. Thus, there was no chance of viral disease transmission through aphids. In West Bengal dehaulming at 65 DAP was found to be safer so far as infestation and chances of viral disease transmission by the sucking pests are concerned as up to $10^{\text {th }}$ January no aphid infestation was noticed in both the years of study. Similar findings were also reported by Das et al. (2016) for potato crop under new alluvial zone of West Bengal.

Effect on post-harvest soil nutrient status: The result showed that the nitrogen, phosphorus and potassium availability in post-harvest soil of potato were not significantly influenced by spacing and dates of haulm cutting but these were significantly influenced by fertility levels. It was clearly evident (Table 6) that, In case of effect of level of spacing the highest soil nitrogen status $\left(178.89 \mathrm{~kg} \mathrm{ha}^{-1}\right)$, soil phosphorus status $\left(18.14 \mathrm{~kg} \mathrm{ha}^{-1}\right)$ and soil potassium status $\left(130.20 \mathrm{~kg} \mathrm{ha}^{-1}\right)$ in post harvest soil was recorded with $20 \mathrm{~cm}$ intra row spacing which might be due to the fact that higher intra row spacing increased the soil nutrient status due to lesser plant population and uptake. Similar observation was also reported by Dua et al. (2008) 
for potato crop at Shimla. In case of dates of haulm cutting effect the highest soil nitrogen status (178.92 $\left.\mathrm{kg} \mathrm{ha}^{-1}\right)$, soil phosphorus status (18.21 $\left.\mathrm{kg} \mathrm{ha}^{-1}\right)$ and soil potassium status $\left(130.20 \mathrm{~kg} \mathrm{ha}^{-1}\right)$ in post harvest soil was recorded with haulm cutting at 65 days after planting which might be due to the fact that decreased growth duration increased the soil nutrient status of potato due to lesser uptake by the crop. In case of fertility levels highest soil nitrogen status $\left(179.73 \mathrm{~kg} \mathrm{ha}^{-1}\right)$, soil phosphorus status $\left(18.28 \mathrm{~kg} \mathrm{ha}^{-1}\right)$ and soil potassium status $\left(130.60 \mathrm{~kg} \mathrm{ha}^{-1}\right)$ in post harvest soil was recorded with $50 \%$ RDF of NPK which might be due to lower uptake by the crop. However, the interaction effects were found non significant at $5 \%$ level of significance.

Nutrient uptake by potato: The result showed that intra row spacing, dates of haulm cutting and fertilizer doses significantly influenced nitrogen, phosphorus and potassium uptake by potato crop (Table 7). With the decrease in intra row spacing from $20 \mathrm{~cm}$ to $15 \mathrm{~cm}$ the uptake of nutrients increased due to increased yield. This finding was corroborated with the findings of Shukla et al. (1976). In case of dates of haulm cutting, the highest nitrogen uptake $\left(135.51 \mathrm{~kg} \mathrm{ha}^{-1}\right)$, phosphorus uptake $\left(37.38 \mathrm{~kg} \mathrm{ha}{ }^{-1}\right)$ and potassium uptake $\left(188.77 \mathrm{~kg} \mathrm{ha}^{-1}\right)$ of potato cultivar Kufri Himalini was recorded with haulm cutting at 75 DAP which might be due to the fact that increased growth duration increased the total tuber yield and nutrient uptake by the crop. In case of fertility levels the highest nitrogen uptake $\left(148.21 \mathrm{~kg} \mathrm{ha}^{-1}\right)$, phosphorus uptake $\left(40.89 \mathrm{~kg} \mathrm{ha}^{-1}\right)$ and potassium uptake $\left(206.47 \mathrm{~kg} \mathrm{ha}^{-1}\right)$ of potato cultivar Kufri Himalini was recorded with $100 \%$ RDF of NPK which might be due to higher tuber yield. The nutrient uptake decreased with the decrease in fertility levels. This result corroborated with the findings of Dua et al. (2008) and Shukla et al. (1976) for potato crops at Shimla.

Economics: It was observed that the net return of potato cultivation varied from Rs. $452226 \mathrm{ha}^{-1}$ to Rs. 604813 ha $^{-1}$ (Table 8). The highest net return $\left(604813 \mathrm{ha}^{-1}\right)$ and $\mathrm{B}$ : $C$ ratio (4.01) was recorded with $15 \mathrm{~cm}$ intra row spacing, 65 DAP of haulm cutting and $50 \%$ of RDF of NPK followed by 15 $\mathrm{cm}$ intra row spacing, 75 DAP of haulm cutting and $50 \%$ of RDF of NPK. Higher economics in potato seed tuber production with decrease in intra row spacing and fertility level was confirmed by Das et al. (2016). The lowest net return (Rs. $452226 \mathrm{ha}^{-1}$ ) was recorded with $20 \mathrm{~cm}$ intra row spacing, and 75DAP of haulm cutting and $100 \%$ RDF of NPK.

\section{Conclusion}

Thus, from the present study it can be concluded that, for quality seed grade potato tuber production use of $50 \mathrm{~cm} \times 15 \mathrm{~cm}$ spacing along with dehaulming at 65 days after planting, when planting is done on first week of November and grown with $50 \%$ RDF of NPK i.e. 100:75:75 kg N:P $\mathrm{O}_{5}$ : $\mathrm{K}_{2} \mathrm{O}$ was found best under New Alluvial Zone West Bengal to get higher numbers of quality seed grade sized potato tubers.

\section{ACKNOWLEDGEMENTS}

The authors are thankful to the All India Coordinated Research Project on Potato, Shimla, H.P. for valuable guidance, encouragement and financial support during the period of this research programme.

\section{REFERENCES}

1. Anonymous (2019). Monthly Report Potato (November), Horticulture Statistics Division, Department of Agriculture, Co-operation and Farmers Welfare, Ministry of Agriculture and Farmers Welfare, Govt. of India, New Delhi.

2. Barclay, G.M., Murphy, H.J., Manzer, F.E., Hutchinson, F.E. (1973). Effects of differential rates of nitrogen and phosphorus on early blight in potatoes. American potato journal. 50(2): 42-48.

3. Chakraborty, A, Konar, A., Banerjee, H. and Jatav, M.K (2013) In: Manual for 'Quality potato seed production in Hooghly district (New Alluvial Zone) of west Bengal. AICRP on Potato, Directorate of Research, BCKV, West Bengal. Pp 1-7.

4. Das, S.K., Sarkar, A., and Chakraborty, A. (2016). Effect of spacing, dates of haulm cutting and fertility levels on quality seed grade tuber production of potato (Solanum tuberosum L.). Indian Agriculturist. 60(3 \&4): 225-236.

5. Directorate of Agriculture, W.B. (2018). Economic Review. Evaluation wing, Directorate of Agriculture, West Bengal, pp. 65.

6. Dua, V.K., Jaiswal, R.C., Khurana, S.C., Kumar, D., Nan-

dekar, D.N., Raghav, M., Rawal, S., Sasani, G.V., Tr ehan, S.P., Trivedi, S.K., Jatav, M.K., Lal, S.S., Thak ur, K.C., Pandey, S.K. and Naik, P.S. (2008). Manipulation of agronomic practices for tuber-size distribution in potato (Solanum tuberosum) seed crop. Indian Journal of Agronomy. 53(3): 217-223.

7. Garg V.K., Deshraj and Sarjeet, S. (1999). Influence of dates of planting and haulms cutting on the yield of seed sized tubers in Shimla Hills. Journal of Indian Potato Association. 26: 7-13.

8. Kumar, V., Singh, G and Tyagi, A. (2017). Evaluation of different fungicides against alternaria leaf blight of tomato. Int. J. Curr. Microbiol. App. Sci. 6(5): 23432350.

9. Lal, S.S. and Sahota, T.S. (1983). Effect of time of planting and lifting on tuber yield of potato in Shillong hills. Journal of Indian Potato Association.10:129133.

10.Mahmud, A.A. Akhter, S., Hossain, M.J., Bhuiyan, M.K.R. and Hoque, M.A. (2009). Effect of dehaulming on yield of seed potatoes. Bangladesh $\mathrm{J}$. Agril. Res. 34(3): 443-448.

11.Malcolimson, J.F. (1976). Assessment of field resistance to late blight (Phytophthora infestans) in potatoes. Transactions of the British Mycological Society. 67: 321-325. 
12.Mitra, K., Naskar, B., Rana, J.P. and Das, S. (2014). Effect of Different Fertilizers Combination on Early Blight of Potato under Diverse Fertility Gradient of Soil. International Journal of Bioresource Science. 1 (1): 73-82

13.Mondal, S.S., Patra, B.C. and Banerjee, H. (2015). Advances in Potato Cultivation Technology. Kalyani Publishers New Delhi. Pp 55-66.

14.Priyank, H.M., Divya, K.L., Venkatasalam, E.P., Aarti, B., Sudha, R and Berliner, J. (2019). Potato cyst nematode: A hidden enemy of potato cultivation in hills. Bhartiya Krishi Anusandhan Patrika. (34): 50-53. DOI: 10.18805/BKAP151
15.Wurr D.C.F. (1978). Seed tuber production and management. In: the potato Crop (P.M. Haris Ed.), Chapman \& Hall, London, pp. 329-354.

16.Wurr, D. C. E., Fellows, J. R., Akehurst, J. M., Hambidge, A. J., \& Lynn., J. R. (2001). The effect of cultural and environmental factors on potato seed tuber morphology and subsequent sprout and stem development. Journal of Agricultural Science, Cambridge. 136: $55-63$

17.Shukla, D.N., Samarjit, Singh and Singh, S. (1976). Effect of plant densities and fertility levels on the dry matter production and nutrient uptake in potato. Indian Journal of Agronomy. 21(4): 408-411. 